\section{(- OPEN ACCESS}

\title{
Multiple cranial nerve injuries and neck abscesses caused by a transorally penetrating organic stick
}

\author{
Satu Lamminmäki, Saku T Sinkkonen, Timo Atula
}

Head and Neck Center, Otorhinolaryngology, Helsinki University Hospital and University of Helsinki, Helsinki, Finland

\section{Correspondence to}

Dr Satu Lamminmäki, satu.lamminmaki@hus.fi

Accepted 30 May 2018
Check for updates

(C) BMJ Publishing Group Limited 2018. Re-use permitted under CC BY-NC. No commercial re-use. See rights and permissions. Published by BMJ.

To cite: Lamminmäki $S$, Sinkkonen ST, Atula T. BMJ Case Rep Published Online First: [please include Day Month Year]. doi:10.1136/ bcr-2017-224021

\begin{abstract}
SUMMARY
Foreign bodies cause a remarkable number of otolaryngological emergency visits and occasionally result in life-threatening conditions and later-emerging complications. Patient recovery depends on the detection and proper extraction of all foreign materials. Despite various obtainable diagnostic tools, adequate anamnesis forms the basis of clinical reasoning and should direct later examinations and radiological imaging. This case report describes a challenging patient with a unique trauma mechanism: many pieces of a fragmented organic foreign body emerged within 1 year of the initial injury, leading to repeated operations, a long period in an intensive care unit and a long-term swallowing and speech dysfunction.
\end{abstract}

\section{BACKGROUND}

Patients with suspected foreign bodies are common in otorhinolaryngological emergency departments. In the aerodigestive tract, the majority of foreign bodies consist of different kinds of ingested ${ }^{1}$ or inhaled ${ }^{2}$ objects. Transoral penetrating foreign bodies often cause palatal lacerations, particularly among paediatric patients who place objects in their mouths. ${ }^{4}$ Typically, the anatomical location of a foreign body in the mouth area is apparent, no radiological diagnostic tests are needed, and removal of an object is relatively straightforward.

This case report describes an adult patient who experienced an extreme, rare transoral foreign body accident resulting in multiple foreign body removal surgeries within 1 year of the injury and various subsequent disabling complications.

\section{CASE PRESENTATION}

A grandfather spent New Year's Day with his grandchildren on the ice of a small lake. From the ice, thick and straight stems of the common cattail (Typha latifolia) protruded. The previously quite healthy 69-year-old grandfather thought those cattails were ideal for use as javelins. Unfortunately, when trying to cut one stem, he slipped and fell forward, at which point a stem penetrated his throat (figure 1, left-most stick). He pulled the broken piece out of his mouth and was initially asymptomatic aside from rather profuse bleeding, most likely increased by his medication. Prior to the accident, he took acetylsalicylic acid and ticagrelor, a platelet aggregation inhibitor, because of a coronary artery stent. Bleeding stopped within $15 \mathrm{~min}$, but he began feeling intense neck pain and speaking became difficult.
At a regional hospital, a small wound (2-cm long), a large submucous haematoma and severe right-side swelling in the patient's soft palate were observed. Unenhanced CT showed strong oedema extending from the nasopharynx to the hypopharynx. Despite the patient's fall on the ice and subsequent neck pain, the cervical spine was intact. Because of increasing swelling and imminent airway obstruction, the patient was fibreoptically intubated and referred to the intensive care unit of the university hospital.

On the third day, the patient had a fever, a bad odour emanated from his mouth and the C-reactive protein level rose from 69 to $258 \mathrm{mg} / \mathrm{L}$. Contrast-enhanced CT-performed for possible deep neck infections-was suspicious for a soft palate abscess. Repeated bedside explorations of the wound unexpectedly revealed two large pieces of cattail (5 and $8 \mathrm{~cm}$ long) deep within the widened wound of the soft palate. However, despite the continuous use of intravenous antibiotics (cefuroxime and metronidazole) and decreasing infection parameters, the patient continued to have a fluctuating fever, and oedema forbade extubation attempts. A bacterial culture from the wound grew Klebsiella pneumoniae. Suspecting residual foreign material, a third CT scan was performed on the 11th day. The images revealed two air-filled, folded tubes in the middle of an abscess at the level of the hyoid bone (figure 2, white arrow). In addition, two hypodense stripes suspicious of foreign bodies were identified below the skull base, extending from the right peritonsillar space near the internal carotid artery, the jugular vein and the vagus nerve (figure 2, black arrow). Under general anaesthesia, pus and a total of five pieces of cattail, two as long as $10 \mathrm{~cm}$, were removed through the original wound in the soft palate (figure 3).

In total, the patient was treated for 22 days in the intensive care unit and for an additional 7 days on a hospital ward. After tracheostomy decannulation (day 17), the right side of the soft palate retracted poorly, the gag reflex was nearly non-existent and an immobile right vocal cord was in the paramedian position, resulting in aspiration and aphonia. Nutrition relied for 1.5 months on a nasogastric tube and an additional 6 months on a percutaneous endoscopic gastrostomy. Aphonia was alleviated with vocal fold augmentation (first with a Radiesse injection, later with autologous fascia ${ }^{5}$ ).

Despite slow improvements in swallowing and the patient's physical condition, the slight right-side neck pain continued. Following physical activity, 


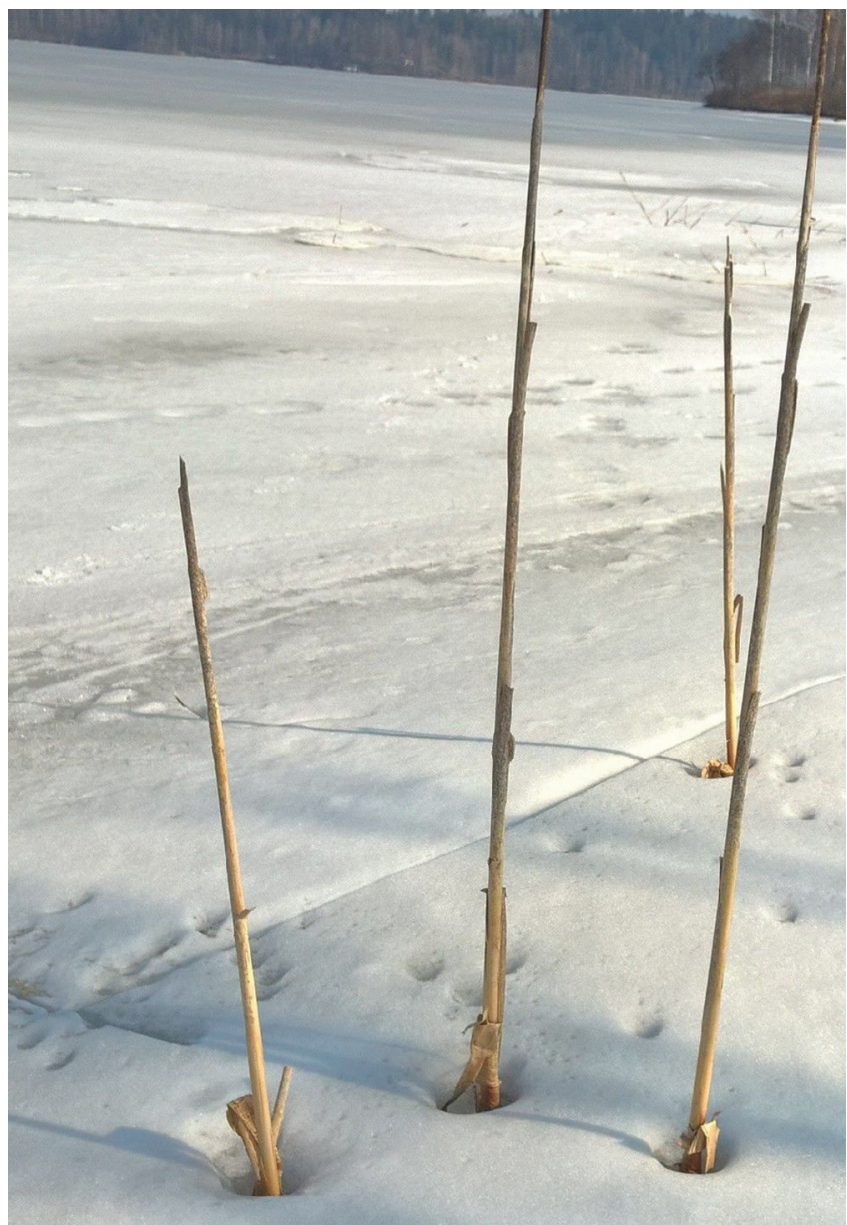

Figure 1 Scene of the accident: the left-most common cattail penetrated deep into the patient's throat (photograph taken 2 months after the accident).

such as cutting firewood with a chainsaw, the neck pain worsened considerably and the pain area swelled for several days. In addition, the patient's grandchildren repeatedly noticed a disagreeable odour emanating from the patient. Eleven months after the accident, MRIs showed a large fluid-filled cavity and a $>5 \mathrm{~cm}$ long foreign body inside the neck muscles. Retrospectively by careful examination, that foreign body was observable in one slice of the very first unenhanced CT images, but not in subsequent CT images. After a nearly 1-year delay, a large amount of pus and a still-hard, solid piece of the cattail were removed from the neck muscles under general anaesthesia (figure 4). Bacterial and fungal cultures from the pus grew no organisms.

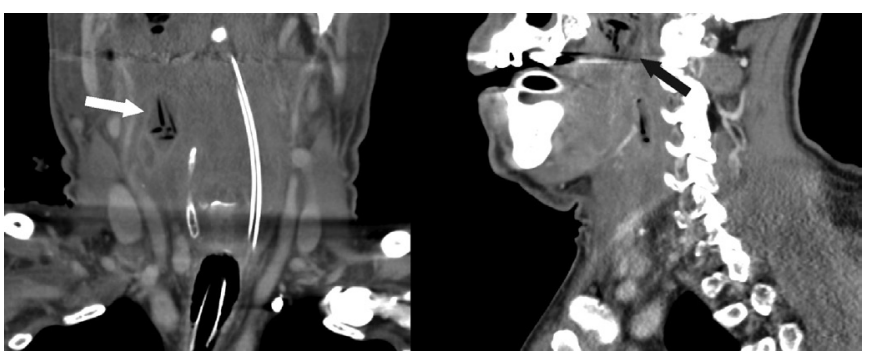

Figure 2 Foreign bodies in contrast-enhanced CT images: air-filled, folded tubes in the middle of an abscess (coronal plane, white arrow); hypodense stripes below the skull base (sagittal plane, black arrow).

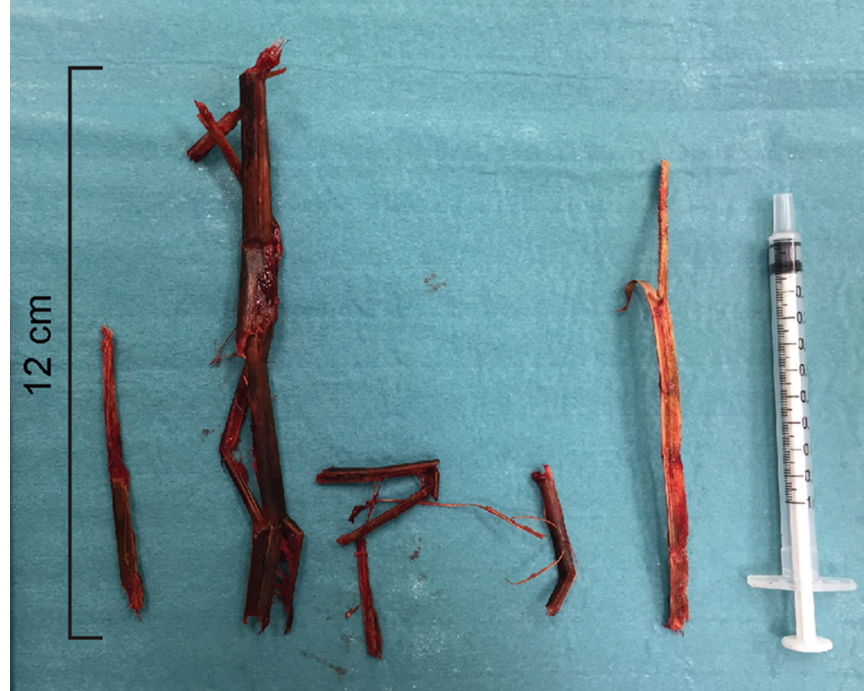

Figure 3 Five pieces of common cattail, removed through the original wound in the soft palate. The right-most piece lacks about a $2 \mathrm{~cm}$ bit cut for bacteria culture.

\section{OUTCOME AND FOLLOW-UP}

One-and-a-half years after the initial accident, the grandfather was finally in sufficiently good condition to plan new javelin competitions with his grandchildren, and no longer smelled badly.

\section{DISCUSSION}

Palatal lacerations usually heal well regardless of intervention. However, in rare cases, transoral penetrating objects have been reported to cause fatal complications such as carotid trauma

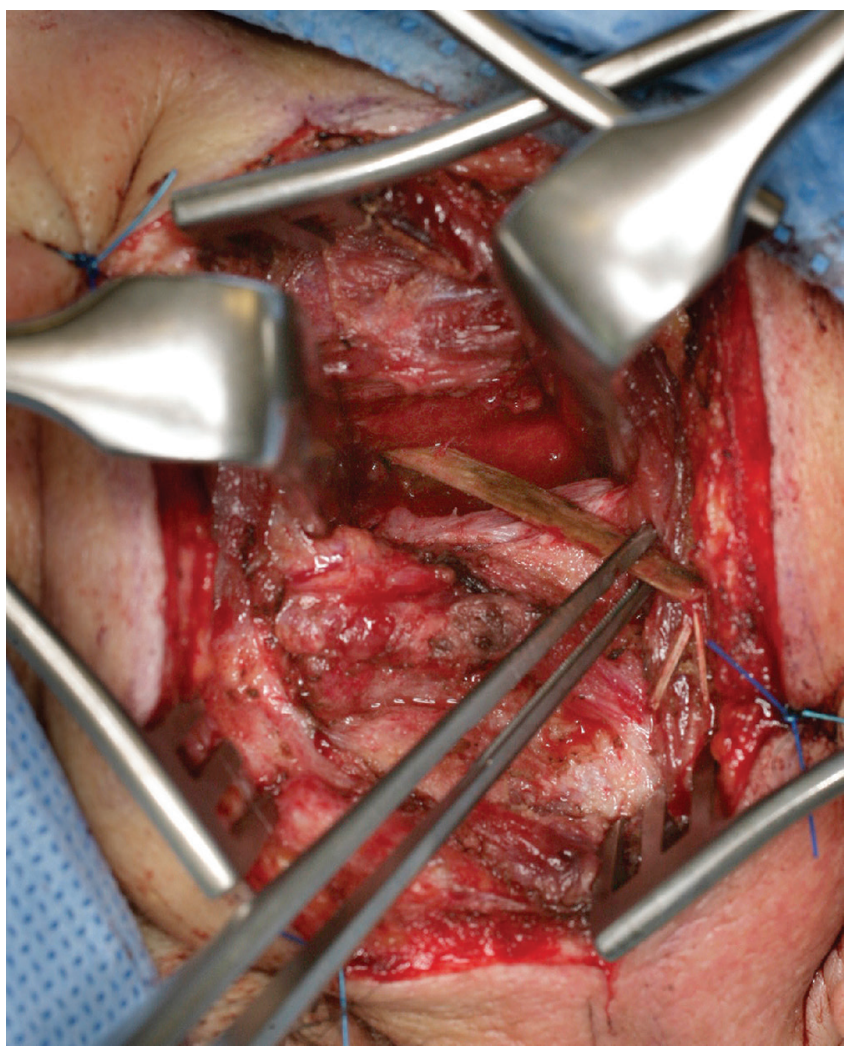

Figure 4 The final removal surgery 1 year after the accident: a $6 \mathrm{~cm}$ long foreign body inside the neck muscles. 
or thrombosis, ${ }^{67}$ intracranial injuries, ${ }^{8}$ mediastinitis or airway obstruction. ${ }^{9}$

Similar to those earlier reported cases, our patient's initial history provided a misleading impression of a rather harmless trauma. No adult eye-witness to the accident existed, and the prior intubation made it impossible to verify the history at the university hospital. Furthermore, the patient's status initially seemed relatively fine; the large haematoma and swelling of the soft palate appeared primarily associated with the patient's anticoagulation medication.

The severe acute and long-lasting, fluctuating mild neck symptoms were interpreted as caused by falling on the ice and of a musculoskeletal origin. Several CT scans and MRIs taken before hospital discharge revealed no other specific reason for the neck pain. Furthermore, during the treatment period on the hospital ward, the severe swallowing and speech difficulties took precedence over the neck pain.

Retrospectively, the air-filled tubes close to the carotid sheath and splinters inside the neck muscles would have been detectable already in the first trauma CT performed at the regional hospital. Yet, they were discovered only after meticulous retrospective examination of the CT scans and with clinical knowledge of their presence and location. It is noteworthy to remember that, especially in emergency care,

\section{Patient's perspective}

In the regional hospital, I was only able to briefly explain what happened. My recollections during the period I was in intensive care are tenuous, such that I experienced alternating reality and hallucinations. I felt that the PEG [percutaneous endoscopic gastrostomy] and the nutrition rehabilitation were appropriate. I benefitted from the vocal cord augmentation and speech therapy. The mysterious neck pain continued throughout the entire treatment period and I felt that it did not receive enough attention. After the long stick inside the nape of the neck was found in the MRI, the stick was removed quickly and successfully.

\section{Learning points}

- Foreign bodies are common reasons for otolaryngological emergency visits.

- Trivial-looking intraoral foreign body injuries can cause lifethreatening complications.

- Frozen, sharp organic foreign bodies can penetrate deep into tissues and fragment into several pieces.

- Unexpected symptoms or setbacks suggest a misdiagnosis. a radiology report largely depends on the phrasing of the question. If a radiological referral does not contain proper information about possible foreign bodies, it may completely escape a radiologist's attention. Moreover, even with the known history about the foreign body accident, the route of the cattail from the throat to as far as the neck is quite extraordinary. Re-examination of the radiological images by a subspecialised radiologist can often yield additional and even crucial information, particularly if the patient's recovery does not proceed as expected.

Reports on frozen penetrating organic foreign bodies remain very scarce. In particular, frozen, sharp organic material may invade deep into the tissues and fragment into several pieces along the penetration route. Special attention must be paid to thoroughly examining the entire route of penetration, and identifying and removing all of the foreign material keeping in mind possible fragmentation.

Acknowledgements The authors thank MD Goran Mahmood for the thorough radiology reports.

Contributors All authors were involved in treating the described patient. TA is the primary physician caring for the patient. SL wrote the manuscript. STS and TA revised the manuscript. All authors approved the final version of the manuscript.

Funding The authors have not declared a specific grant for this research from any funding agency in the public, commercial or not-for-profit sectors.

Competing interests None declared.

Patient consent Obtained.

Provenance and peer review Not commissioned; externally peer reviewed.

Open access This is an open access article distributed in accordance with the Creative Commons Attribution Non Commercial (CC BY-NC 4.0) license, which permits others to distribute, remix, adapt, build upon this work non-commercially, and license their derivative works on different terms, provided the original work is properly cited, appropriate credit is given, any changes made indicated, and the use is non-commercial. See: http://creativecommons.org/licenses/by-nc/4.0/.

\section{REFERENCES}

1 Kim SY, Park B, Kong IG, et al. Analysis of ingested foreign bodies according to age, type and location: a retrospective observational study. Clin Otolaryngol 2016;41:640-5.

2 Blanco Ramos M, Botana-Rial M, García-Fontán E, et al. Update in the extraction of airway foreign bodies in adults. J Thorac Dis 2016;8:3452-6.

3 Berdan EA, Sato TT. Pediatric airway and esophageal foreign bodies. Surg Clin North Am 2017;97:85-91.

4 Radkowski D, McGill TJ, Healy GB, et al. Penetrating trauma of the oropharynx in children. Laryngoscope 1993;103:991-4.

5 Rihkanen H. Vocal fold augmentation by injection of autologous fascia. Laryngoscope 1998;108:51-4.

6 Randall DA, Kang DR. Current management of penetrating injuries of the soft palate. Otolaryngol Head Neck Surg 2006;135:356-60.

7 Sasaki T, Toriumi S, Asakage T, et al. The toothbrush: a rare but potentially lifethreatening cause of penetrating oropharyngeal trauma in children. Pediatrics 2006;118:e1284-6.

8 Samuthrat T, Ye K, Tong Y. Transoral Intracranial Injury via Middle Skull Base by a Blunt Chopstick in a Child. World Neurosurg 2017;103:952.e11-952.e17.

9 Law RC, Fouque CA, Waddell A, et al. Lesson of the week. Penetrating intra-oral trauma in children. BMJ 1997:314:50-1. 
Copyright 2018 BMJ Publishing Group. All rights reserved. For permission to reuse any of this content visit http://group.bmj.com/group/rights-licensing/permissions.

BMJ Case Report Fellows may re-use this article for personal use and teaching without any further permission.

Become a Fellow of BMJ Case Reports today and you can:

- Submit as many cases as you like

- Enjoy fast sympathetic peer review and rapid publication of accepted articles

- Access all the published articles

- Re-use any of the published material for personal use and teaching without further permission

For information on Institutional Fellowships contact consortiasales@bmjgroup.com

Visit casereports.bmj.com for more articles like this and to become a Fellow 